\title{
Hubungan kepadatan tungau debu rumah dengan derajat rinitis alergi
}

\author{
${ }^{1}$ Billy G. Mantu \\ ${ }^{2}$ Greta J. Wahongan \\ ${ }^{2}$ Janno B. Bernadus
}

\author{
${ }^{1}$ Kandidat Skripsi Fakultas Kedokteran Universitas Sam Ratulangi Manado \\ ${ }^{2}$ Bagian Parasitologi Klinik Fakultas Kedokteran Universitas Sam Ratulangi Manado \\ Email: billymantu@gmail.com
}

\begin{abstract}
Alergic Rhinitis (AR)is a global health burden and a big problem that can cause disability all over the world. AR prevalence in Asia today has increase approximately 45\%, and occurs in poorest and develop country. House Dust Mite (HDM) can cause AR. That's because HDM is prime allergen that live in dust and grow optimaly in $25-30^{\circ} \mathrm{C}$ with humidty above 60\%. 100-500 HDM expose is a risk factor for development allergic reaction. This study aimed to know the relationship between the density of HDM with the degree of AR. This was an observational-analitic study with a cross-sectional design. The results showed that the average of HDM in bedroom is 192, and 376 in lounge. There were 17 people that affect AR Intermittent and 13 people that affect AR persistent. For mild symptoms there are 25 people and for moderat-severe symptoms there are 5 people. Conclusion:There is no relationship about density of HDM with the degree of AR.
\end{abstract}

Keywords: House Dust Mite, Allergic Rhinitis

\begin{abstract}
Abstrak: Rinitis alergi merupakan masalah kesehatan global dan merupakan masalah besar yang dapat menyebabkan disabilitas di seluruh dunia Prevalensi rinitis alergi di Asia terakhir mengalami peningkatan yaitu sekitar 45\% dan paling banyak di negara miskin dan berkembang.Salah satu penyebab rinitis alergi adalah Tungau Debu Rumah (TDR). Hal tersebut karena TDR merupakan alergen utama yang terdapat pada debu rumah yang ada dimana-mana, dan berkembang di tempat tidur, bantal, karpet, perabot rumah tangga dengan suhu $25^{\circ} \mathrm{C}-30^{\circ} \mathrm{C}$, dan kelembaban tinggi $>60 \%$.Pajanan tungau sebanyak 100-500 tungau per gram atau $10 \mathrm{mg}$ Der p 1 per gram debu merupakan faktor risiko terjadinya reaksi alergi. Penelitian ini bertujuan untuk mengetahui hubungan antara kepadatan tungau debu rumah dengan derajat rinitis alergi. Penelitian ini termasuk jenis penelitian observasional-analitik dengan pendekatan cross sectional untuk mengetahui hubungan kepadatan tungau debu rumah dengan derajat rinitis alergi. Hasil penelitian memperlihatkan rata-rata jumlah kepadatan TDR di kasur sebanyak 192 tungau per gram debu., di sofa sebanyak 376 tungau per gram debu. Untuk derajat rinitis alergi yaitu Intermittent adalah sebanyak 17 orang responden (56,67\%) dan Persistent sebanyak 13 orang responden (43,33\%). Sedangkan untuk berat gejalanya yaitu ringan adalah sebanyak 25 orang responden (83,33\%), sedang-berat adalah sebanyak lima orang responden (16,67\%). Simpulan:Tidak terdapat hubungan yang bermakna antara hubungan kepadatan tungau debu rumah dengan derajat rinitis alergi.
\end{abstract}

Kata kunci: Tungau Debu Rumah, Rinitis Alergi

Rinitis alergi merupakan masalah kesehatan global dan merupakan masalah besar yang dapat menyebabkan disabilitas di seluruh dunia. Prevalensi rinitis alergi di Asia terakhir mengalami peningkatan yaitu sekitar $45 \%$ dan paling banyak di negara miskin dan berkembang. Rinitis alergi adalah peradangan mukosa hidung yang diperantarai oleh IgE yang diinduksi setelah terekspos alergen dan ditandai oleh tiga tanda kardinal yaitu bersin-bersin, hidung tersumbat, dan rinore/hidung berair. Reaksi ini timbul akibat paparan terhadap bahan yang pada umumnya tidak berbahaya dan banyak ditemukan dalam lingkungan yang biasa disebut sebagai alergen.,

Debu rumah bagi sekelompok orang tertentu merupakan komponen alergen inhalan yang penting karena berperan 
terhadap timbulnya berbagai reaksi alergi. Di dalam debu rumah terdapat Tungau Debu Rumah (TDR) yang merupakan faktor risiko signifikan terjadinya alergi di banyak negara. $^{2-4}$

Bagian tubuh TDR yang biasa menjadi alergen yaitu kutikula, organ seksual, saluran pencernaan, TDR yang sudah mati serta tinjanya yang merupakan alergen potensial. ${ }^{5}$ Antigen yang berasal dari tubuh TDR masuk ke dalam tubuh manusia melalui penetrasi kulit, sedangkan yang berasal dari faeces masuk ke tubuh manusia melalui inhalasi.

Morfologi tubuh TDR pada umumnya berbentuk bulat atau oval dimana kepala, thorax, dan abdomennya menyatu. Permukaan tubuhnya tampak transparan dengan garis-garis berlekuk dalam yang tampak baik dari sisi ventral maupun dorsal. Tubuhnya juga memiliki rambut-rambut panjang yang disebut setae yang muncul dari tepi luar tubuhnya. Ukuran tubuh TDR bervariasi, berkisar antara 0,2-0,3 mm. TDR bersifat ovipar. Dalam perkembangannnya TDR melalui empat tahapan yaitu telur, larva, nympha, dan bentuk dewasa. ${ }^{4}$

Kepadatan TDR merupakan jumlah TDR yang terdapat dalam satu gram debu. Pajanan tungau sebanyak 100-500 tungau per gram atau $10 \mathrm{mg}$ Der p 1 per gram debu merupakan faktor risiko terjadinya reaksi alergi. Pajanan lama dengan 500 tungau per gram debu atau lebih mengakibatkan terjadinya respons antibodi IgE. ${ }^{6}$

\section{Definisi Dan Etiologi Rinitis Alergi}

Rinitis alergi adalah inflamasi IgE spesifik mukosa hidung setelah terpapar dengan alergen yang ditandai dengan tiga tanda kardinal yaitu bersin-bersin, hidung tersumbat, dan rinore/hidung berair. Penyebabnya sendiri dapat diakibatkan oleh bulu binatang, serbuk sari, kecoa,

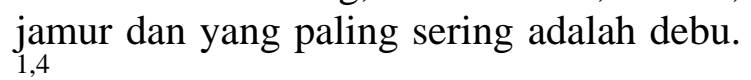

\section{Klasifikasi Rinitis Alergi}

Klasifikasi terbaru rinitis alergi telah dibuat oleh WAO (World Allergy Organisation) ARIA (Allergic Rhinitis and Its Impact on Asthma) yaitu dari lama gejala dibagi dua, yaitu Intermittent atau dibawah empat hari perminggu atau dibawah satu bulan dan Persistent atau diatas empat hari perminggu dan diatas sat bulan. Dari berat gejala dibagi dua juga yaitu ringan jika gejala tidak mengganggu tidur, aktivitas, olahraga, rekreasi, bekerja, belajar dan tidak ada gejala yang sangat mengganggu dan sedang sampai berat jika terdapat satu atau lebih gejala diatas. ${ }^{1,7}$

\section{Patogenesis Alergi dan Rinitis Alergi}

Reaksi alergi terdiri dari 2 fase, yaitu reaksi alergi fase cepat (RAFC) yang berlangsung sejak kontak dengan alergen sampai 1 jam setelah kontak dan reaksi alergi fase lambat (RAFL) yang berlangsung 2-4 jam dengan puncak 6-8 jam (fase hiper-reaktivitas) setelah terpapar alergen dan dapat berlangsung sampai 2448 jam. Dalam patogenesisnya, reaksi alergi dibedakan dalam dua fase yaitu fase sensitisasi dan elisitasi yang terdiri atas tahap aktivasi dan tahap efektor. ${ }^{6}$

\section{Fase Sensitisasi}

Semua mukosa hidung manusia terpapar oleh berbagai partikel, seperti tepung sari, debu, serpihan kulit binatang, dan protein lain yang terhirup bersama inhalasi udara napas. Sel dendritik merupakan antigen presenting cell (APC) di paru-paru dan berperan penting pada respon imun alergen inhalan seperti tungau debu rumah. Pada kontak pertama dengan alergen, makrofag atau sel dendritik yang berperan sebagai APC akan menangkap aeroalergen yang menempel di permukaan mukosa hidung. Alergen yang terdeposit pada mukosa hidung tersebut kemudian diproses oleh makrofag/ sel dendritik yang berfungsi sebagai fagosit dan APC menjadi peptida pendek yang terdiri atas 7-14 asam amino yang berikatan dengan tempat pengenalan antigen dari komplek MHC (major histocompatibility complex) kelas II. APC ini akan mengalami migrasi ke 
adenoid, tonsil atau limfonodi yang kemudian dipresentasikan pada sel Th naif (Th0). ${ }^{6,8}$

Pada penderita atopi, reseptor sel $\mathrm{T}$ (TCR) pada limfosit Th0 bersama molekul CD4 dapat mengenali peptida yang disajikan oleh sel penyaji antigen tersebut. APC melepas sitokin, seperti IL-1, yang akan mengaktifkan Th0 untuk berproliferasi menjadi Th1 dan Th2. Th2 menghasilkan berbagai sitokin, seperti IL3, IL-4, IL-5, dan IL-13. Produksi sitokin berlebihan oleh TH2 di paru-paru merupakan salah satu penyebab timbulnya asma. ${ }^{6,9}$

Paparan alergen dosis rendah terusmenerus pada seseorang yang mempunyai bakat alergi (atopi) dan presentasi alergen oleh sel-sel dari APC pada sel B disertai pengaruh sitokin IL-4 dan IL-13 yang diikat oleh reseptornya di permukaan sel limfosit B, memicu sel limfosit B menjadi aktif dan akan memproduksi IgE yang terus bertambah jumlahnya. IgE spesifik tersebut berikatan di permukaan sel mast dan memiliki peran penting dalam timbulnya reaksi alergi akut. Sel mast kemudian masuk ke venula postkapiler di mukosa yang kemudian keluar dari sirkulasi dan berada dalam jaringan, termasuk di mukosa dan sub-mukosa hidung. Dalam keadaan ini, seseorang dikatakan dalam keadaan sensitif atau sudah tersensitisasi, serta memberikan hasil positif pada uji kulit., ${ }^{6,10}$

\section{Fase Elisitasi}

\section{Tahap Aktivasi}

Pada penderita yang sudah mengalami sensitisasi, jika terpapar ulang dengan alergen serupa dengan paparan alergen sebelumnya pada mukosa hidung, dapat terjadi ikatan/bridging antara dua molekul IgE yang berdekatan pada permukaan sel mast/basofil dengan alergen yang polivalen tersebut (cross-linking). Interaksi antara IgE yang terikat pada permukaan sel mast atau basofil dengan alergen yang sama tersebut memicu aktivasi guanosin trifosfat (GTP) yang mengaktifkan enzim fosfolipase C untuk mengkatalisis fosfatidil inositol bifosfat (PIP2) menjadi inositol trifosfate (IP3) dan diasilgliserol (DAG) pada membran PIP2. Inositol trifosfat (IP3) menyebabkan pelepasan ion kalsium intrasel $(\mathrm{Ca}++)$ dari retikulum endoplasma. Ion $\mathrm{Ca}++$ dalam sitoplasma langsung mengaktifkan beberapa enzim, seperti fosfolipase-A dan komplek $\mathrm{Ca}++-k a l m o d u l i n \quad y a n g$ mengaktifkan enzim myosin light chain kinase. Selanjutnya, $\mathrm{Ca}++$ dan DAG bersama-sama dengan membran fosfolipid mengaktifkan protein kinase C. Sebagai hasil akhir aktivasi ini adalah terbentuknya mediator lipid yang tergolong dalam newly formed mediators, seperti prostaglandin D2 (PGD2) leukotrien C4 (LTC-4), platelet activating factors (PAF), dan eksositosis granula sel mast yang berisi mediator kimia yang disebut sebagai preformed mediator seperti histamin, triptase, dan bradikinin. Penelitian oleh Post dkk menunjukkan bahwa tungau debu rumah dapat menjadi salah satu penyebab timbulnya sinyal kalsium pada sel epitel bronkial dan berperan dalam produksi mediator kimiawi. ${ }^{6,11}$

Histamin memiliki efek langsung pada endotel, yaitu meningkatkan permeabilitas kapiler yang menyebabkan proses transudasi yang memperberat gejala rinore. Ikatan histamin pada reseptor saraf nosiseptif tipe $\mathrm{C}$ pada mukosa hidung yang berasal dari N.V menyebabkan rasa gatal di hidung dan merangsang timbulnya serangan bersin. Efek histamin pada kelenjar karena aktivasi refleks parasimpatis mempunyai efek meningkatkan sekresi kelenjar yang menyebabkan gejala rinore yang serous, Selain itu, juga menyebabkan gejala hidung tersumbat karena menyebabkan vasodilatasi pembuluh darah sehingga terjadi transudasi ke interstisial yang mengakibatkan mukosa hidung, terutama konka, menjadi edema. Gejala yang segera timbul setelah paparan alergen disebut reaksi fase cepat atau reaksi fase segera (RFS). Histamin yang sudah dibebaskan 
dari sel mast akan dimetabolisme oleh histamine $\mathrm{N}$-methyl transferase (HMT) pada sel epitel ataupun pada endotel. ${ }^{6}$

\section{Tahap Efektor}

Setelah reaksi fase aktivasi, dengan adanya pelepasan sitokin dan aktivasi endotel, terjadi reaksi fase lambat. Reaksi fase lambat (RFL) terjadi pada sebagian penderita (30-35\%) rinitis alergi antara 4-6 jam setelah paparan alergen dan menetap selama 24-48 jam. Gambaran khas RFL adalah tertariknya berbagai macam sel inflamasi, khususnya eosinofil ke lokasi reaksi alergi yang merupakan sel efektor mayor pada reaksi alergi kronik, seperti rinitis alergi dan asma bronkhial. Perjalanan eosinofil dari sirkulasi darah sampai ke jaringan/lokasi alergi dipengaruhi faktor kemotaktik, melalui beberapa tahap seperti migrasi (perpindahan) eosinofil dari tengah ke tepi dinding pembuluh darah dan mulai berikatan secara reversibel dengan endotel yang mengalami inflamasi (rolling), diikuti perlekatan pada dinding pembuluh darah yang diperantarai oleh interaksi molekul adhesi endotel, seperti intercell adhesion molecule-1 (ICAM-1) dan vascular cell adhesion molecule-1 (VCAM-1) yang bersifat spesifik terhadap perlekatan sel eosinofil karena sel eosinofil mengekpresikan VLA-4 yang akan berikatan dengan VCAM-1. ICAM-1 juga diekspresikan oleh sel epitel mukosa hidung penderita rinitis alergi yang terpapar alergen spesifik terus-menerus dan menjadi dasar konsep adanya minimal persistent inflamation (MPI) yang terlihat pada rinitis alergi terhadap tungau debu rumah (TDR) dalam keadaan bebas gejala. Sel eosinofi l mukosa hidung berperan penting pada perubahan patofisiologis penderita alergi, karena mengandung berbagai mediator kimia, seperti major basic protein (MBP), eosinophile cationic protein (ECP), eosinophile derived neurotoxin (EDN), dan eosinophile peroxidase (EPO) yang menyebabkan desagregasi dan deskuamasi epitel, kematian sel, inaktivasi saraf mukosa, dan kerusakan sel karena radikal bebas. ${ }^{6}$

\section{Alergen Tungau Debu Rumah}

Bagian tubuh TDR yang bisa menjadi alergen yaitu kutikula, organ seksual, saluran pencernaan dan TDR yang sudah mati serta tinjanya yang merupakan allergen potensial. Antigen pada $D$. pteronyssinus terutama di saluran cerna dan kutikula. Makanan yang masuk ke usus diekskresikan sebagai antigen yang kuat. Dalam masa 3 bulan kehidupannya, tungau diperkirakan menghasilkan 2000 partikel tinja, 50 telur, dan 4 kutikula, sehingga secara tidak langsung memperlihatkan bahwa $>95 \%$ alergen tungau berasal dari partikel tinja. 5,6

TDR merupakan organisme yang kompleks dan memiliki banyak variasi protein yang dapat merangsang antibody IgE pada individu yang poten. Salah satu dari alergen tersebut disebut Der $\mathrm{p} 1$ dan Der f 1. Der p 1 merupakan protease sistein yang memiliki aktivitas enzimatik yang berhubungan dengan sensitisasi alergi. Alergen tersebut mempunyai berat molekul (BM) 24 kilodalton (kd). Der p 1 mempengaruhi aktivitas sistein protease, sehingga menyebabkan deskuamasi sel-sel epitel, lepasnya sitokin oleh sel epitel, dan membawa alergen melewati lapisan epitel. 6,12

Alergen kedua (Der p II, Der f II) berasal dari badan tungau yang mempunyai BM $15 \mathrm{kd}$, diameternya $250 \mu \mathrm{m}$. Alergen tersebut lebih stabil pada suhu panas. Der $\mathrm{p}$ 2 sangat sedikit berpengaruh pada aktivitas protease, tetapi dapat berikatan dengan Ig E. Der p 2 dapat menginduksi imunitas Th2 dengan mengaktifkan TLR4 yang diekspresikan oleh sel epitel bronkial. ${ }^{6,13}$

Alergen lainnya pada TDR yang lain yaitu alergen III (Der f III) dengan BM 30 kd dan mempunyai struktur kimia sama dengan tripsin, sedangkan alergen IV mempunyai BM 60 kd dengan struktur kimia sama dengan amilase. TDR mengandung alergen dari feses lebih dari 200 kali berat tubuhnya. Pajanan tungau 
sebanyak 100-500 tungau per gram atau 10 mg Der p 1 per gram debu merupakan faktor risiko terjadinya asma. Pajanan lama dengan 500 tungau per gram debu atau lebih mengakibatkan terjadinya respons antibodi IgE dan asma. ${ }^{6}$

\section{Peranan Tungau Debu Rumah Dalam Proses Terjadinya Rinitis Alergi}

Alergen kelompok 1 TDR protease sistein dan aktivitas proteasenya berkontribusi dalam timbulnya alergi. Kemampuan proteolitik dari Derp 1 dan Derf 1 menyebabkan kerusakan tight junction pada kelompok protein transmembran okludin dan claudin dan melekat pada reseptor CD23 dan CD25. Hal tersebut akibatnya menyebabkan pertahanan epitel bocor dan meningkatkan kemungkinan terjadinya kontak alergen dengan sel penyaji antigen. Kerusakan tersebut juga menyebabkan timbulnya respon sel Th2 dan pelepasan sitokin proinflamasi dari sel epitel bronkial, sel mast, dan basofil. Hal ini menyebabkan timbulnya sintesis antibody IgE dan inflamasi di epitel paru yang dapat berperan dalam timbulnya asma. ${ }^{14,15}$

Mekanisme yang jelas tentang bagaimana alergen Der p 2 mempengaruhi sel Th2 masih belum pasti sampai sekarang. Beberapa penelitian menunjukkan bahwa Der p 2 strukturnya homolog dengan MD2 (lipid binding kofaktor TLR4), sehingga membentuk inflamasi saluran napas melalui mekanisme toll like receptor-4 (TLR4). Der p 2 yang dimurnikan dari TDR mengandung sedikit lipopolisakarida (LPS) dan dapat mengaktivasi TLR4 yang tidak mengandung MD2, jadi dalam hal ini LPSDer p 2 mungkin mirip dengan LPS-MD2 dalam mengaktivasi TLR4. Rekombinan Der p 2 yang tidak memiliki LPS tidak mengaktifkan jalur tersebut. Sensitisasi saluran napas oleh Der p $2(0,1 \mu \mathrm{g})$ dalam kondisi rendah paparan LPS (0,026 pg) dapat menyebabkan toleransi pada mencit wild type dan mencit defisit MD, tetapi tidak terjadi pada mencit defisit TLR4.
Karena Der p 2 meniru fungsi MD2, akibatnya Der p 2 menampilkan adjuvan yang penting dalam respons alergi TDR. Penelitian lain menunjukkan bahwa Der $\mathrm{p}$ 2 merangsang sel-sel otot polos saluran pernapasan melalui mekanisme TLR 4independent. ${ }^{6}$

Penelitian oleh Sundaru ${ }^{26}$ menunjukkan bahwa paparan TDR menimbulkan sensitisasi asma pada $77 \%$ responden yang diteliti. Di negara tertentu seperti Korea, TDR merupakan alergen inhalan yang paling penting dan memiliki tingkat paparan yang signifikan. Lebih dari 31 alergen merupakan hasil ekstraksi dari TDR. Hal ini menunjukkan TDR merupakan salah satu penyebab penting timbulnya alergi. ${ }^{17}$

\section{METODE PENELITIAN}

Penelitian ini termasuk jenis penelitian observasional-analitik dengan pendekatan cross sectional untuk mengetahui hubungan antara kepadatan tungau debu rumah dengan derajat rinitis alergi.Penelitian dilaksanakan pada bulan Oktober 2015-Januari 2016.Sampel diambil dengan menggunakan teknik purposive sampling. Penentuan besarnya sampel ditentukan dengan menggunakan rumus komparatif analitik numerik tidak berpasangan yang didapati hasil sebanyak 30 sampel.

\section{HASIL PENELITIAN}

Dari hasil analisis deskriptif menunjukkan bahwa rata-rata usia responden adalah 32,77 tahun dengan usia termuda 4 tahun dan tertua 64 tahun. Ratarata jumlah penghuni rumah adalah 5,33 orang dengan jumlah penghuni terendah 1 orang dan tertinggi 10 orang. Rata-rata jumlah penghuni yang tidur di kasur sampel adalah 2 orang dengan jumlah penghuni terendah 1 orang dan tertinggi 4 orang. Rata-rata kepadatan kasur dan sofa masing-masing adalah 192,23 dan 376,03, kepadatan tertinggi masing-masing berjumlah 1138 dan 2003, sedangkan kepadatan terendah keduanya sama-sama 
berjumlah nol.

Tabel 1. Distribusi responden berdasarkan jenis kelamin.

\begin{tabular}{lll}
\hline Jenis & $\mathrm{N}$ & $\%$ \\
Kelamin & 9 & 30 \\
Laki-laki & 21 & 70 \\
Perempuan & 30 & 100 \\
Total & \\
\hline
\end{tabular}

Dari hasil penelitian menunjukkan bahwa jumlah responden laki-laki adalah sembilan orang (30\%) dan lebih sedikit jauh dari jumlah responden perempuan yaitu 21 orang (70\%).

Hasil penelitian selanjutnya didapatkan berat debu kasur rata-rata 0,118 gram, sofa 0,242 gram, dengan berat minimum 0,060 gram dan berat maksimum 1,020 gram.

Untuk jumlah kisaran tungau pada kasur didapatkan data sebanyak 0-180 tungau berada pada 30 sampel (100\%), sedangkan untuk jumlah tungau 181-360 dan 361-550 tungau adalah sebanyak nol sampel (0\%). Jumlah maksimum TDR yang didapatkan pada kasur adalah 109. Jumlah minimum adalah nol tungau dengan rata-rata 16,23 tungau.

Dari hasil penelitian didapatkan kepadatan TDR pada kasur paling banyak adalah dibawah 600 tungau per gram debu (90\%), diikuti kepadatan TDR 600-1200 tungau (10\%) dan kepadatan TDR paling sedikit adalah diatas 1200 tungau per gram debu (0\%). Jumlah maksimum kepadatan TDR yang ditemukan pada kasur sampel per gram debu adalah sebanyak 1138 tungau, sedangkan jumlah minimum kepadatan TDR yang ditemukan adalah sebanyak nol tungau dengan rata-rata jumlah kepadatan TDR yang ditemukan di kasur sampel sebanyak 192 tungau per gram debu. Untuk sofa, kepadatan TDR paling banyak adalah dibawah 600 tungau per gram debu (76,67\%), diikuti kepadatan 600-1200 tungau per gram debu (13,33\%) dan kepadatan diatas 1200 tungau per gram debu merupakan kepadatan dengan jumlah sampel terkecil (10\%). Jumlah maksimum kepadatan TDR yang ditemukan pada sofa sampel adalah sebanyak 2003 tungau per gram debu, sedangkan jumlah minimumnya sebanyak nol tungau per gram debu dengan rata-rata jumlah kepadatan TDR yang ditemukan di sofa sampel adalah sebanyak 376 tungau per gram debu.

Dari hasil penelitian diatas didapatkan hasil derajat rinitis alergi untuk lama berlangsungnya yaitu Intermittent adalah sebanyak 17 orang responden (56,67\%) dan Persistent sebanyak 13 orang responden (43,33\%). Sedangkan untuk berat gejalanya yaitu ringan adalah sebanyak 25 orang responden (83,33\%), sedang-berat adalah sebanyak lima orang responden $(16,67 \%)$.

\section{BAHASAN}

\section{Usia Subjek Penelitian}

Dari hasil penelitian dapat kita lihat bahwa usia subjek berkisar antara 4-64 tahun dengan rata-rata mur 33 tahun. Hal ini berbeda dengan penelitian sebelumnya yang dibuat oleh Hadi $\mathrm{dkk}^{18}$ yang menggunakan kriteria sampel dibawah remaja awal dengan rata-rata 7 tahun dengan total sampel sebanyak 41 responden.

\section{Kepadatan Tungau dalam Penelitian}

Kepadatan tungau pada kasur berkisar antara 0-1138 tungau per gram dengan rata-rata 192 tungau per gram. Kepadatan sofa berkisar antara 0-2003 tungau per gram dengan kepadatan rata-rata sebanyak 376 tungau per gram dengan kepadatan tertinggi didapati pada sofa. Hal ini berbeda dengan penelitian sebelumnya yang dilakukan oleh Walangare $\mathrm{dkk}^{5}$ yang mendapati kepadatan tungau pada kasur dan sofa masing-masing sebanyak 16 dan 20 tungau per gram dengan kepadatan tertinggi pada kasur tetapi didukung oleh El-Nadia $^{19}$ yang mengatakan dalam satu gram debu terdapat sekitar 1000 tungau dan Nadchatram ${ }^{20}$ yang mengatakan bahwa dalam satu gram debu terdapat \pm 10.000 
TDR. Hal ini disebabkan karena perbedaan kekuatan vaccum cleaner yang digunakan dan cara pengambilan sampel dimana kekuatan vaccum cleaner peneliti sebesar 800 watt sedangkan kekuatan vaccum cleaner milik walangare sebesar 400 watt ditambah dengan cara pengambilan sampel peneliti yang mengambil sampel lebih lama di tempat-tempat yang terlipat dan sulit dijangkau dimana banyak terdapat tungau yang bersembunyi.

\section{Jumlah dan Kepadatan TDR}

Kepadatan tungau terbanyak terdapat pada sofa dibandingkan dengan kasur. Ini disebabkan karena pada rumah yang didapati, faktor kebersihannya sangat jarang diperhatikan. Seperti jarang membersihkan sofa, sering makan di sofa, tidak pernah membersihkan sisa makanan di sofa dan lain-lain. Ditambah lagi dengan faktor orang yang sering berkunjung dan duduk di sofa seperti yang dijelaskan diatas, serta berat debu yang didapati lebih banyak ditemukan di sofa, maka hal ini dapat menyebabkan jumlah dan kepadatan tungau meningkat. ${ }^{5,21}$

\section{Derajat Penyakit Rinitis Alergi dan Hubungannya dengan Kepadatan TDR}

Pada hasil penelitian dapat kita lihat bahwa derajat penyakit rinitis alergi responden kebanyakan didapati dengan derajat ringan. Begitupun dengan hasil analisis hubungan kepadatan TDR dengan derajat rinitis alergi yang didapati tidak terdapat hubungan yang bermakna. Kedua hal ini saling menunjang karena kepadatan TDR dengan derajat rinitis alergi tidak berhubungan sehingga meskipun banyak tungau yang ditemukan tetapi kebanyakan responden hanya menderita rinitis dengan derajat ringan. Hal ini dikarenakan sistem imun pada tiap individu yang atopi bersifat sangat kompleks dan subjektif, sehingga didapati derajat sensitisasi yang berbedabeda pada tiap individu. Penelitian ini ditunjang juga dengan hasil penelitian dari Xing $\mathrm{dkk}^{22}$ yang menyatakan bahwa tidak terdapat hubungan yang bermakna antara kepadatan TDR dengan serangan rinitis alergi. Hal ini dapat diselidiki lebih lanjut dengan pemeriksaan sistem imun tiap individu yang sayangnya tidak dilakukan peneliti dan menjadi salah satu kelemahan dari penelitian ini. Hal ini dapat menjelaskan kenapa kepadatan TDR tidak memiliki hubungan yang bermakna dengan derajat rinitis alergi. 6,10

\section{SIMPULAN}

Dari hasil penelitian yang dilakukan terhadap para responden di kota Manado, maka dapat disimpulkan:

1. Jumlah TDR dan debu terbanyak yang ditemukan dalam penelitian terdapat pada bagian sofa sampel.

2. Jumlah TDR terbanyak yang ditemukan pada kasur dan sofa masing-masing berada pada kisaran suhu $28-30^{\circ} \mathrm{C}$ dan $31-33^{\circ} \mathrm{C}$.

3. Jumlah TDR terbanyak yang ditemukan pada kasur dan sofa masing-masing berada pada kisaran kelembaban 71-80\%.

4. Tidak terdapat hubungan yang bermakna antara hubungan kepadatan tungau debu rumah dengan derajat rinitis alergi.

\section{DAFTAR PUSTAKA}

1. Pawankar R, Bunnag C, Khaltaev N, Bousquet J. Allergic Rinitis and Its Impact on Asthma in Asia Pacific and the ARIA Update 2008. WAO journal. 2012;212-7.

2. Wistiani, Notoatmojo H. Hubungan pajanan alergen terhadap kejadian alergi pada anak. Sari Pediatri. 2011;13(3):185-90.

3. Paramita OD, Harsoyo N, Setiawan H. Hubungan asma, rinitis alergik,dermatitis atopik dengan IgE spesifik anak usia 6-7 tahun. Sari Pediatri. 2013;14:391-7.

4. Yudopranoto K. Perbandingan populasi tungau debu rumah pada kasur kapuk dan non kapuk di perumahan pjka kelurahan randusari semarang selatan jawa tengah. [skripsi]. Semarang: 
Universitas Diponegoro; 2006.

5. Walangare KR, Tuda JSB, Runtuwene J. Tungau debu rumah di kelurahan taas kecamatan tikala kota manado. Jurnal e-Biomedik (eBM). 2013;1: 439-44.

6. Natalia D. Peranan alergen tungau debu rumah (der p 1 dan der p 2) dalam reaksi alergi. CDK-227. 2015;42:2515.

7. Irianto K. Parasitologi medis. Edisi ke2. Bandung: Alfabeta Bandung; 2010. h. 251-2.

8. Plantinga $\mathrm{M}$, Guilliams $\mathrm{M}$, Vanheerswynghels $M$, Deswarte $K$, Madeira F-B, Toussaint W, et al. Conventional and monocyte-derived cd $11 \mathrm{~b}+$ dendritic cells initiate and maintain $t$ helper 2 cell-mediated immunity to house dust mite allergen. Immunity. 2013;38:322-35.

9. Halim TYF, Krauß RH, Sun AC, Takei F. Lung natural helper cells are a critical source of Th2 cell-type cytokines in protease allergen-induced airway inflammation. Immunity. 2012;36:451-63.

10. Galli SJ, Tsai M. IgE and mast cells in allergic disease. Nat Med. 2013;18(5):693-704.

11. Post S, Nawijn MC, Jonker MR, Kliphuis N, Berge MVD, Oosterhout AJMV, et al. House dust mite-induced calcium signaling instigates epithelial barrier dysfunction and CCL20 production. Allergy. 2013;68:1117-25.

12. Henriquez OA, Beste KD, Hoddeson EK, Parkos CA, Nusrat A, Wise SK. House dust mite der $\mathrm{p} 1$ effects on sinonasal epithelial tight junctions. Int Forum Allergy Rhinol. 2013;3(8): 6305.

13. Willart MAM, Deswarte K, Pouliot P, Braun H, Beyaert R, Lambrecht BN, et al. Interleukin-1 $\alpha$ controls allergic sensitization to inhaled house dust mite via the epithelial release of GM-CSF and IL-33. J. Exp Med. 2012;209:1505-17.

14. Chruszcz M, Pomés A, Glesner J, Vailes LD, Osinski T, Porebski PJ, et al. Molecular determinants for antibody binding on group 1 house dust mite allergens. J Biol Chem. 2012;287(10):7388-98.

15. Newton GK, ${ }^{\dagger}$ Perrior TR, ${ }^{\dagger}$ Jenkins $\mathrm{K}^{\dagger}$ Major MR, ${ }^{\dagger}$ Key RE, ${ }^{\dagger}$ Stewart MR, ${ }^{\dagger}$ et al. The discovery of potent, selective, and reversible inhibitors of the house dust mite peptidase allergen der $\mathrm{p} 1$ : an innovative approach to the treatment of allergic asthma. J Med Chem. 2014;57:9447-62.

16. Sundaru H. House dust mite allergen level and allergen sensitization as risk factors for asthma among student in central Jakarta. Med J Indones. 2006;15:55-9.

17. Jeong KY, Park JW, Hong CS. House dust mite allergy in korea: the most important inhalant allergen in current and future. Allergy Asthma Immunol Res. 2012;4(6):313-25.

18. Hadi S. Hubungan kepadatan tungau debu rumah dengan derajat penyakit dermatitis atopik. [Tesis]. Semarang: Universitas Diponegoro; 2002.

19. EL-Dib NA. House dust mites - what might a mite do ? EOLSS. 2002;2:1,7.

20. Nadchatram M. House dust mites, our intimate associates. Tropical Biomedicine. 2005;22(1): 23-37.

21. Ponggalunggu $\mathrm{B}$, Pijoh V, Wahongan GJP. Jenis dan kepadatan tungau debu rumah pada beberapa habitat di rumah penderita penyakit alergi. Jurnal eBiomedik (eBm). 2015;3:254-60.

22. Xing Z, Li J, Wang M, Wang G, An S, $\mathrm{Yu}$ D. The relationship between the density of house dust mite allergens in bedroom and the attacks of allergic rhinitis. Journal of Clinical Otorhinolaryngology. 2003;17(9):5479. 